\title{
Naturfolk og nature morte
}

af idehistoriker Lars Morell

I efteråret 1994 lavede Pia Arke den serie fotografier, der nu er erhvervet af Kort- og Billedafdelingen, og som vises på de følgende sider. Anledningen var, at Susanne Mortensen, der er kvinden på billederne, havde gennemgået en længerevarende behandling for kræft, der var endt med en operation. På en måde deler Pia Arke og Susanne Mortensen fælles skæbne.

De kommer begge fra den samme by, Scoresbysund, der er den meget isolerede og noget omdiskuterede by på Grønlands østkyst. Som store børn rejste de begge til Danmark for at uddanne sig, Pia Arke studerede på Det kgl. danske Kunstakademi, og Susanne Mortensen læste eskimologi på Københavns Universitet, og siden mødte de hinanden påny. Susanne Mortensen fik kræft og måtte gå til behandling. Senere brød kræften frem igen. Hver gang kørte Pia Arke med til undersøgelserne i bil gennem det nordsjællandske landskab til Frederikssund. De havde lange samtaler i bilen, mens landskabet og årstiderne forandrede sig udenfor.

Resultatet af de ulykkelige begivenheder er denne serie fotografier. Umiddelbart er det en mærkelig blanding af fotografier af Susanne Mortensen og optagelser lavet på Marinens Bibliotek, der dengang lå på Christianshavn, men som siden er blevet flyttet til Holmen. Her findes der en sjælden samling af gamle bøger om Grønland, som opbevares under opsyn i et sikringsrum. Næsten alle billederne er taget i dette lokale.

De 10 fotografier, sådan som de findes i Kort- og Billedsamlingen, har meget forskellig størrelse. Nogle er ret store, og andre er temmelig små. Alle er i sort/ hvid. De blev først præsenteret ved et seminar på Sostrup Slot, hvor de på en lidt collageagtig måde var hængt op på væggen som en mangfoldig helhed. Det er Pia Arke, som selv har bestemt den grafiske fremtoning her i Magasin, hvor 


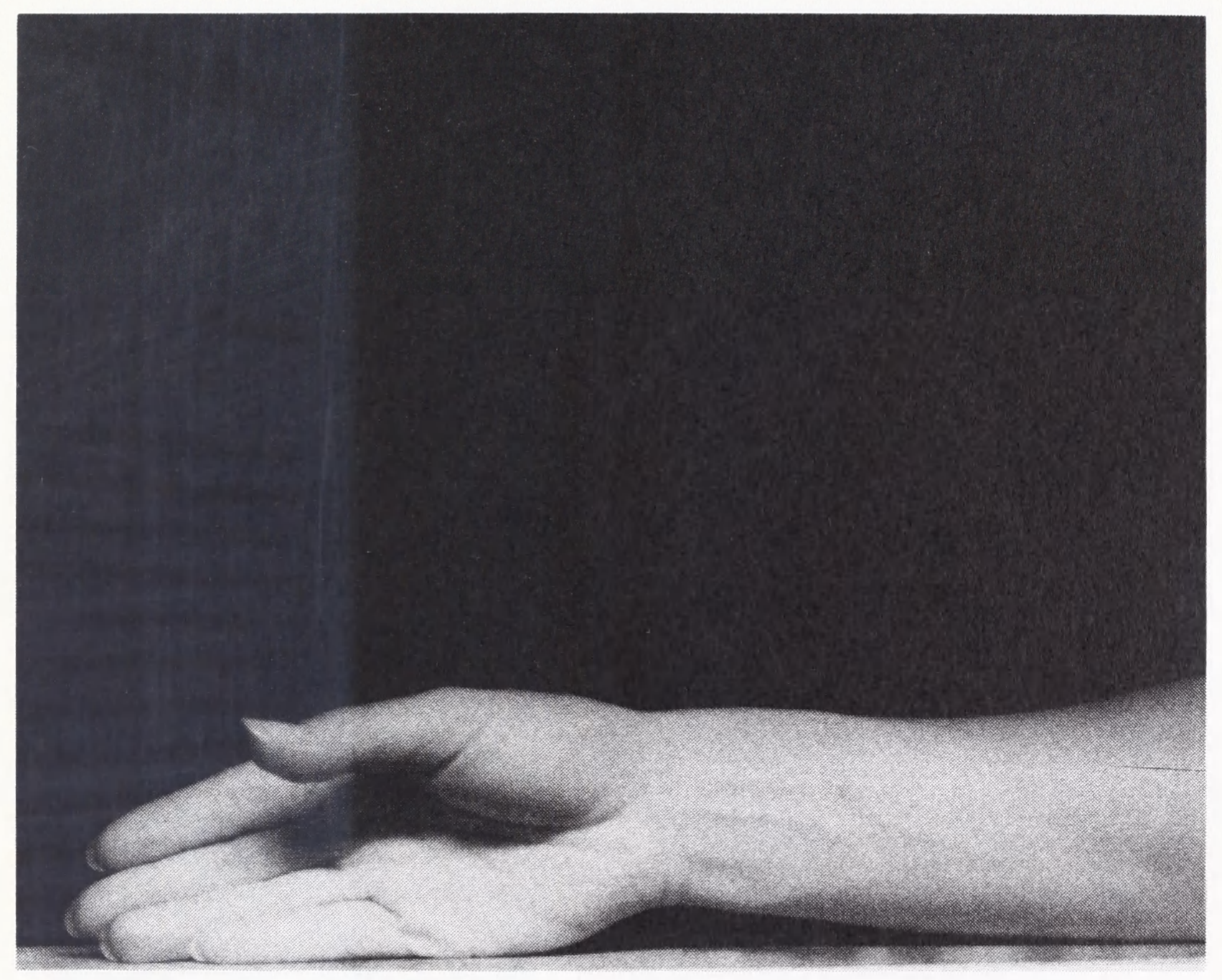




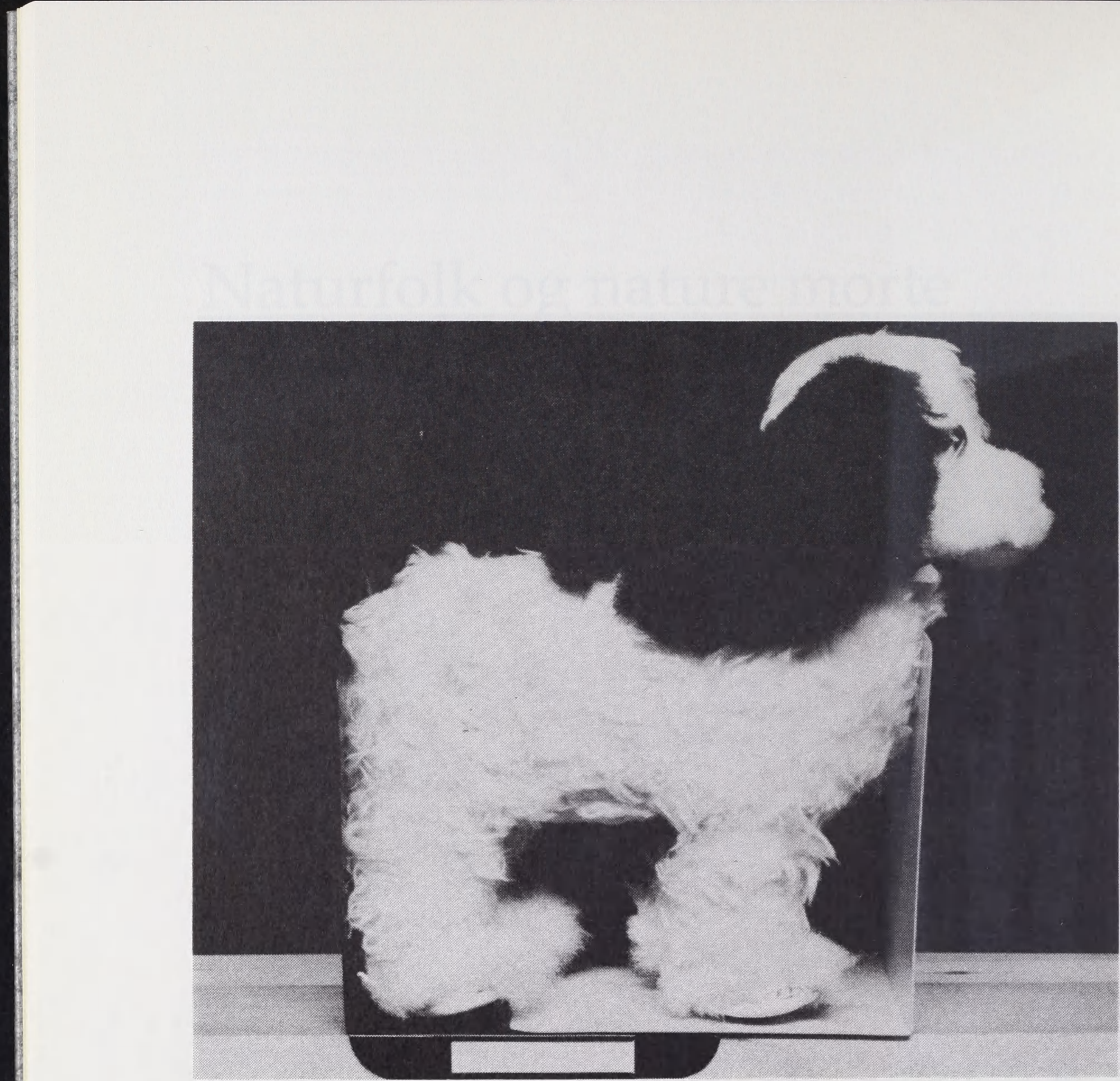




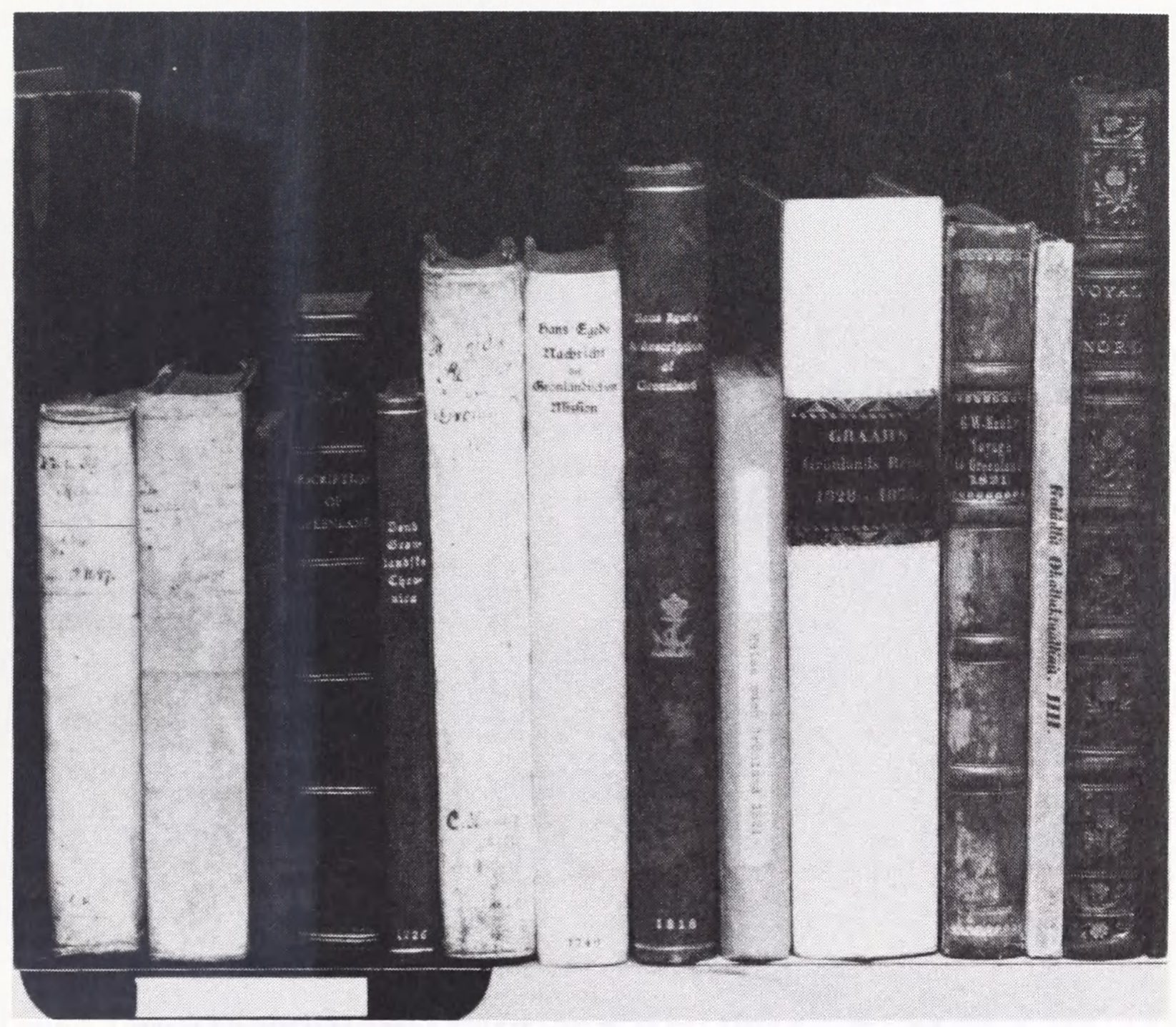




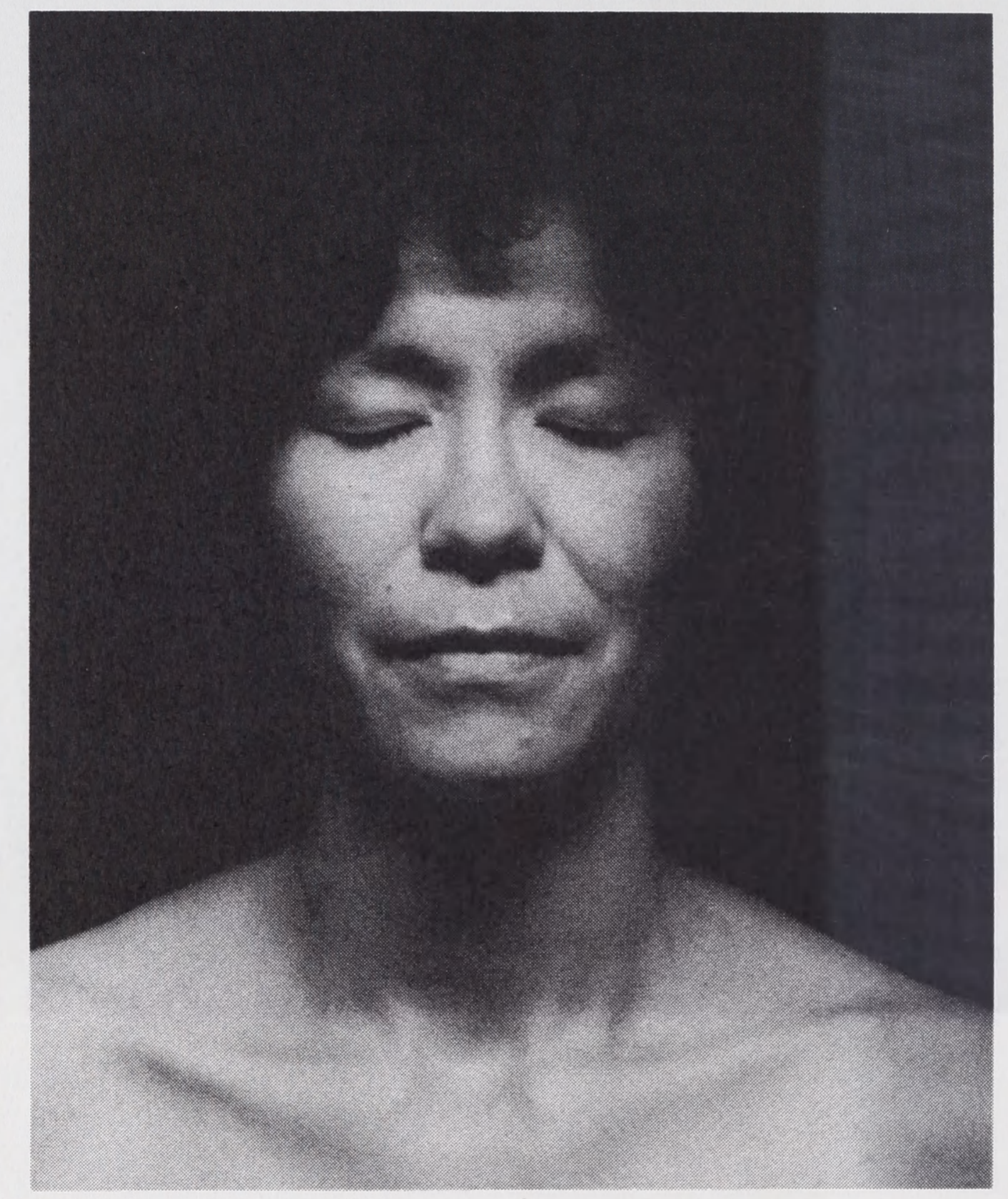


alle billederne stort set har samme størrelse og kommer lineært det ene efter det andet.

Første billede viser Pia Arkes egen udstrakte arm med den åbne hånd. Her starter serien. Det modsvarer det sidste billede med hånden, der lukker sig ned mod hylden, så serien på en måde samler sig om sig selv.

Andet billede forestiller en tøjhund, som Pia Arke som barn fik foræret af en amerikaner. Det har nok været mens familien boede i Dundas nær Thulebasen, men hun var for voldsom mod hunden, så hendes mor gemte den. Måske har det noget at gøre med naturen, i hvert fald den tæmmede natur, udover at det handler om barndommen, minderne og måske også om Grønlands forhold til Danmark og USA.

Tredje fotografi afbilder et antal bøger om Grønland fra Marinens Bibliotek. Man kan genkende hylden og bogstøtten fra reolen. Baggrunden er beklædt med et sort klæde sat op til lejligheden. Fotografens egen hånd og tøjhunden var iøvrigt optaget samme sted.

Fjerde billede viser ansigtet på en kvinde. Hun er også fotograferet i sikringsrummet på Marinens Bibliotek. Hendes ansigtstræk ser ikke danske ud. Hun har lukkede øjne. Er hun død, eller sover hun og drømmer? Vi ser på billedet, men billedet ser ikke på os. Det er i sin egen tillukkede, smertelige verden.

Femte billede viser arret efter et bortopereret bryst. Selv i vore dage er det et motiv, man sjældent ser offentliggjort. Vi kan endnu ikke være helt sikre på, at der er en forbindelse mellem ansigtet på det fjerde billede og torsoen på det femte.

Med sjette billede er vi tilbage i bibliotekets egen verden, hvor tre af de gamle bøger om Grønland ligger med en tommestok oven på. Før stod bøgerne lodret. Nu ligger de vandret. Det er som om, de er på vej ud af reolen for at blive åbnet.

Syvende billede bekræfter, at det er kvinden med de lukkede øjne, som har det bortopererede bryst. Vi ved, at det er Susanne Mortensen, men denne viden er vel ikke nødvendig for at tilnærme sig billedet. Protesen ligger på hendes højre lår. Nu har hun åbnet øjnene og taget brillerne på. Hun stirrer lige ud imod os. Viser sig frem.

Der er et vendepunkt her, og det ottende billede er også anderledes end de foregående. Nu er en af de lukkede bøger endelig blevet slået op, og vi ser en illustration fra Hans Egede's Det gamle Grønlands nye perlustration. Oprindeligt valgte Arke denne illustration, fordi mændene og kvinderne står i en rundkreds. Det er den samme runde form som på såret og protesen. Det viste sig siden, at billedet forestiller et helbredelsesritual. 


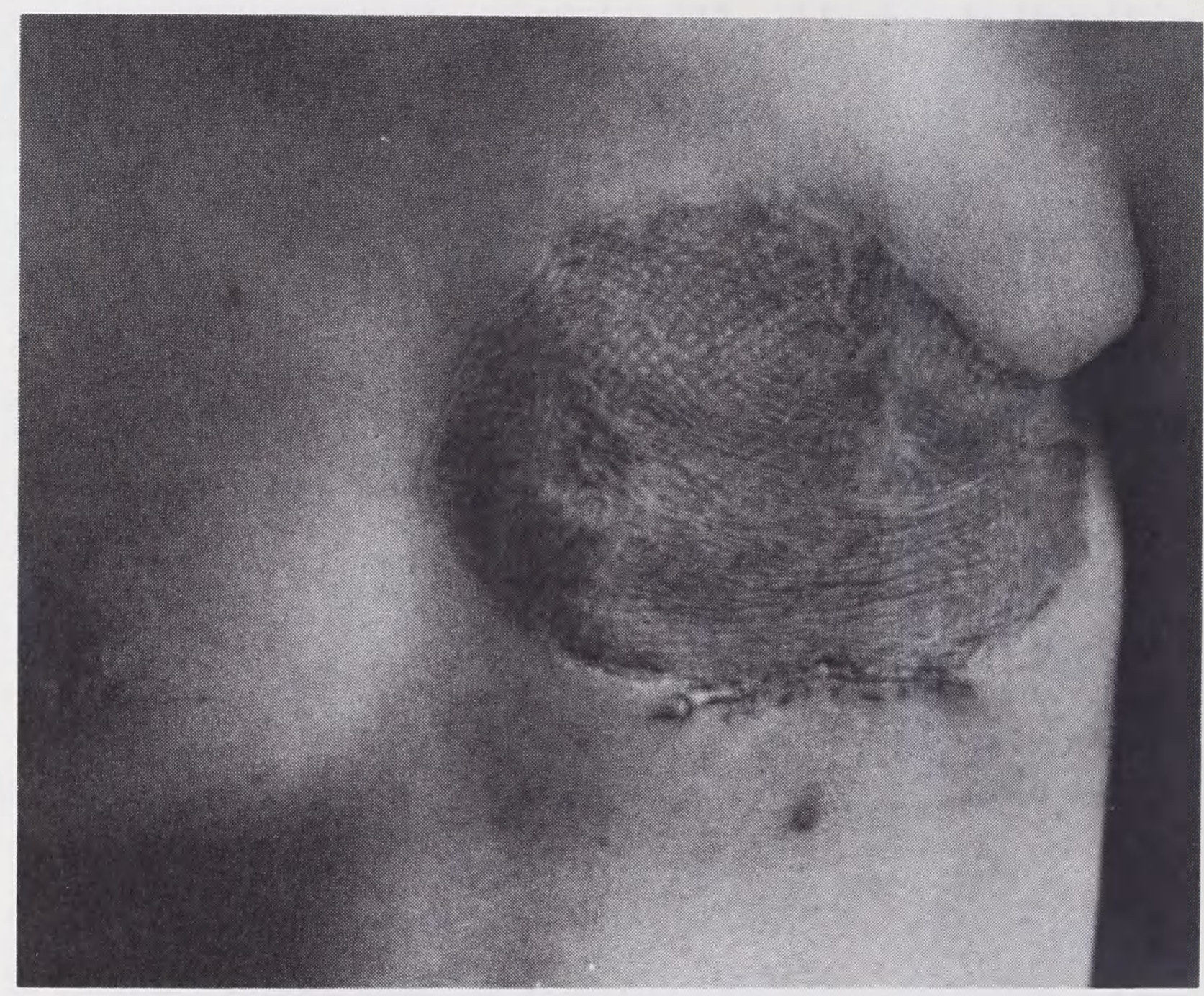




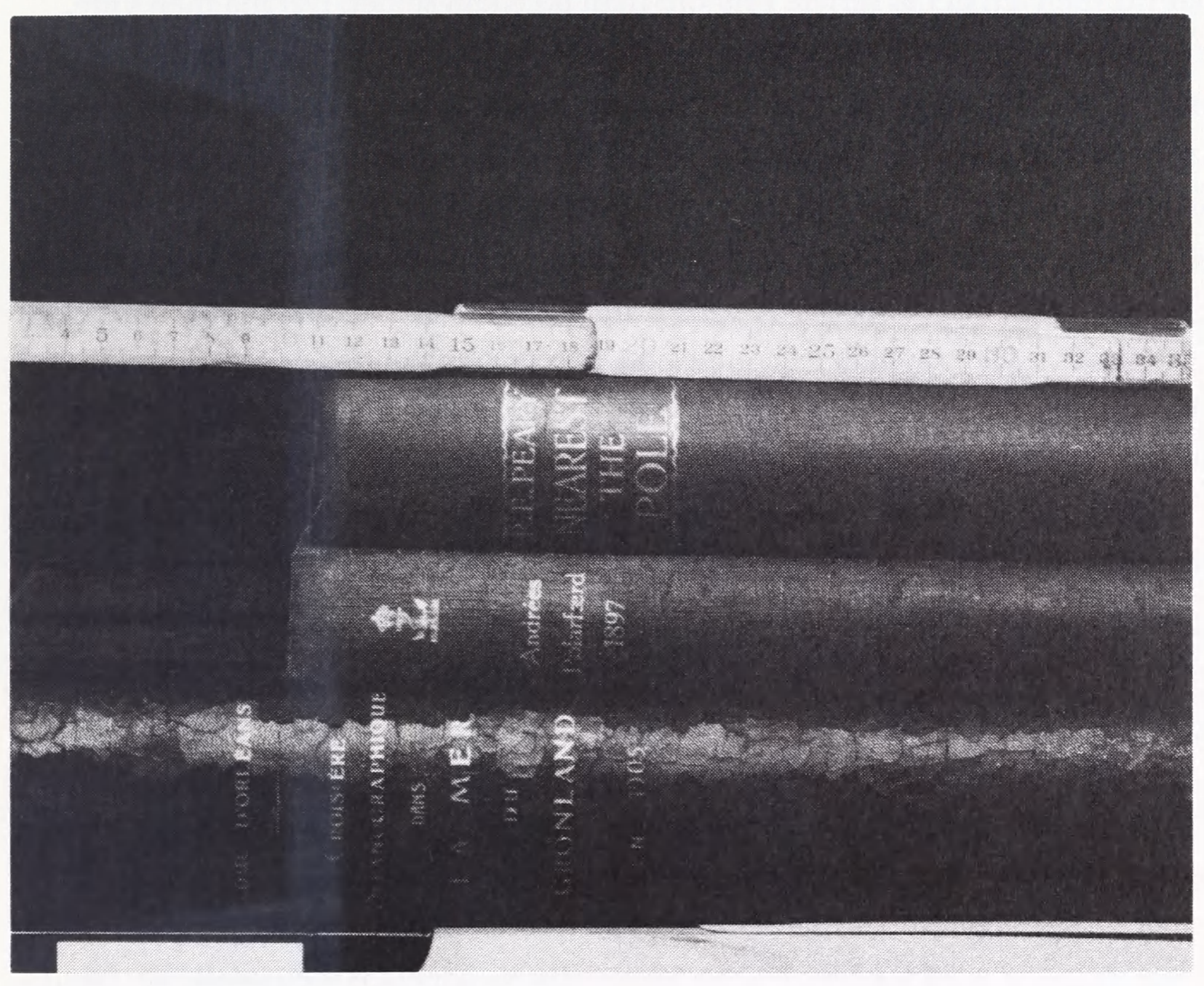


På niende foto er bøgerne igen lukkede og sat tilbage lodret på deres plads i reolen. Der ligger en tændstikæske oven på.

Tiende billede er det tidligere omtalte, hvor Arkes egen hånd lukker sig ned mod hylden og derved slutter forløbet. Både med legetøjshunden og med armen er hun selv en del af serien, selv om man ikke kan se det. Det må man vide.

Billedet og især fotografiet er øjeblikkets kunst. Det enkelte billede kan ikke fortælle en hel historie, men højst gengive en enkelt scene. Løsningen på problemet er at lave en serie billeder, som viser et forløb og dermed et før, et nu og et efter. Her er det handlingen, der skaber forbindelsen.

En serie kan også være den minimalistiske serie, sådan som især Mel Bochner har defineret den (Louisiana Revy, 12. årgang nr. 1). Her er serien ikke baseret på gentagelse. Den er heller ikke baseret på det eksistentielle valg, som ligger i handlingen. Den er afhængig af strenge, logiske systemer, der transformerer det foregående element over i de efterfølgende.

Det er en tredje form for serie, vi møder i de 10 fotografier af Pia Arke. Her er hverken handling eller logik. Istedet hænger billederne sammen til et kompliceret netværk. Hvad er forbindelsen mellem bøgerne og Susanne Mortensen? Svaret er kompliceret, men hænger sammen med, at hun studerede eskimologi ved Københavns Universitet. Hun har læst i de bøger og er på en måde blevet syg af at læse dem - $i$ hvert fald hvis vi tænker på, at bøgernes affattelse hænger samme med historien om Grønland og Danmark og dermed også den kendsgerning, at Susanne Mortensen måtte rejse fra sin by, fra sit land, fra sit sprog og leve mange tusinde kilometer borte. Ind i dette komplicerede spind af forbindelser føjer sig tøjhunden, helbredelses-ritualet og Pia Arkes udstrakte hånd i en blanding af private og fælles-menneskelige temaer.

I de senere år har man talt en del om etnisk kunst, men det er svært at komme uden om den kendsgerning, at Pia Arke er uddannet som kunstner og fotograf ved Det kgl. danske Kunstakademi med hvad dertil hører af kunsthistorisk indsigt. Hendes billeder er beslægtet med malerkunsten, hvor portrættet og opstillingen er to af de mest kendte genrer. Optagelserne af Susanne Mortensen er naturligvis portrætter. Alle de øvrige billeder med armen, tøjhunden og bøgerne er opstillinger. De er opbygget meget traditionsbevidst. Stoffet, som danner den sorte baggrund, er pausen og tavsheden. Herfra kommer der intet udsagn. Bogreolens hylde erstatter i dette tilfælde bordkanten i den traditionelle nature morte. Hylden eller den vandrette bordkant, hvorpå opstillingen rejser sig lodret, udgør hele billedets arkitektonik. Netop arkitektonikken er meget stærk i Arkes fotografier med de rektangulære bogrygge, der stables så de vandrette og lod- 
rette linjer kommer i balance med hyldens og billedets kanter.

Bøger er et velkendt motiv fra stilleben billeder, hvor de optræder som en allegori over forgængeligheden. På Pia Arkes fotografier er guldskriften på omslagene allerede halvt ulæselig. Bladene er gulnede. Læderbindene revnede.

Nature morte er det første tema, der er fælles for de enkelte billeder i Pia Arkes serie. Det er ikke bare bøgerne, der er forkrænkelige. Legetøjet vækker erindringer om barndommen, der er forsvundet. Tiden er gået, og minderne er tilbage. Det er også Susanne Mortensen, der er angrebet af den livsfarlige måske dødelige kræftsygdom. Endelig er det grønlænderne, naturfolket der er en nature morte, fordi den fangerkultur, som etnograferne snakker om, og som bøgerne dokumenterer, ikke mere eksisterer.

Tændstikæsken oven på bøgerne er også et forgængelighedstegn. På de traditionelle nature morte'r svarer det til kærten, der brænder ned, og som er en allegori over tiden, der går, og livet, som svinder. Ilden er et forgængelighedstegn, fordi den hurtigt kan destruere alle de skrøbelige papirer og lade dem gå op i flammer. Tændstikæsken ligger oven på bøger skrevet af Hans Egede og hans to sønner. Det er ikke en hvilken som helst æske tændstikker, men en æske Tordenskjolds, fordi Poul Egede ville være søofficer, men måtte følge faders vilje og blive præst. Svovlet og ilden hentyder til, at Hans Egede var alkymist og dermed til det mystiske element midt i hans kristendom og oplysningstrang.

Videnskaben er billedernes andet fælles tema. Den videnskabelige viden er skrevet ned i bøgerne i form af optegnelser og analyser. Tegningen af grønlændernes helbredelsesritual er udtryk for, at den vestlige videnskab i form af etnografien foretager optegnelser af naturfolkenes liv. Både bøgerne og Susanne har et corpus eller et legeme, som på hver sin måde er udtryk for videnskabens dissekerende fremgangsmåder. Corpus'et og caesur'en. Lægens skalpel har lagt et snit ned gennem kroppen, ganske som videnskabens analyser lægger et snit gennem virkeligheden ved at findele den i stadig mindre bestanddele. Det fraskårne er givet tilbage som en protese af kunststof, ganske som videnskaben giver virkeligheden tilbage i form af abstraktioner. Bøgerne lukker sig i deres magtfulde utilgængelighed. Systematikken kommer til syne i skikkelse af det lille mærke til klassifikation af bøgerne, som findes nederst på hver bogstøtte.

Tavsheden er det tredje tema i Pia Arkes billedserie. Der er altid tavshed om de mest livsfarlige sygdomme. Kræft vil ramme mange af os, men vi lader som om, det ikke kommer os ved. Skammen over den tabuiserede sygdom blandet med angst for døden skaber tavsheden. Dermed tangerer serien et tema, som gennemsyrer næsten alt, hvad Pia Arke har lavet. Alle mennesker ruger over 


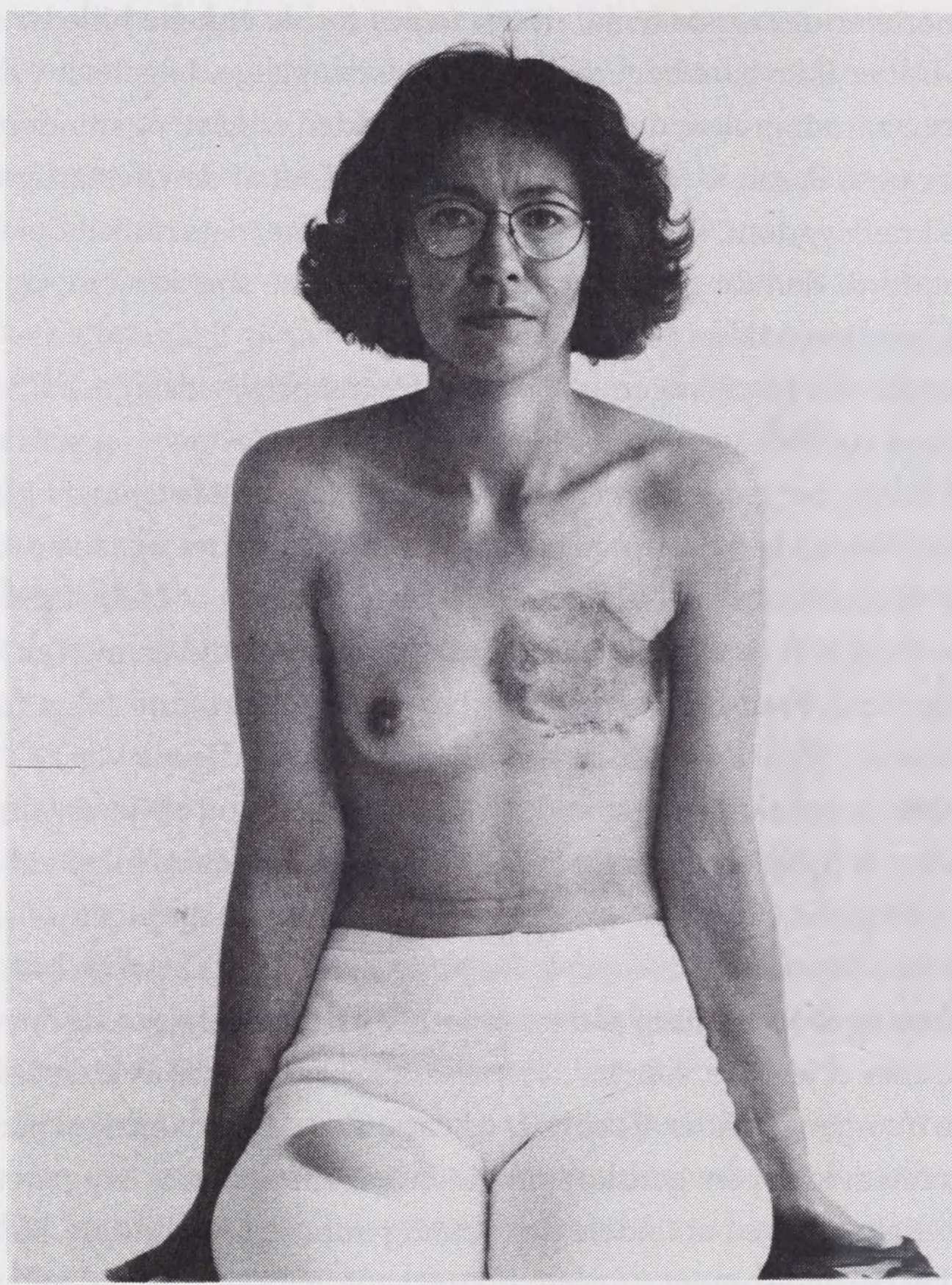




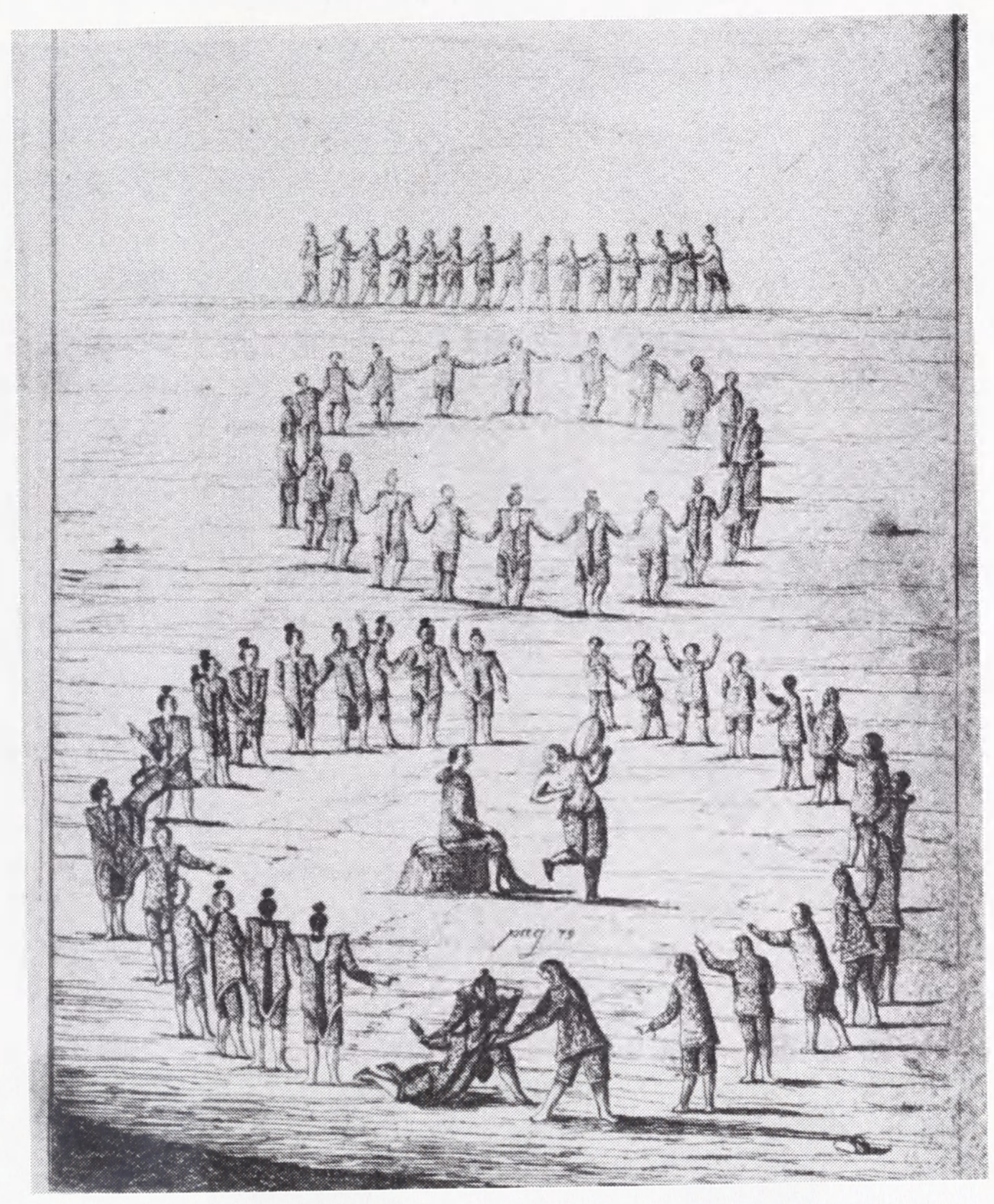




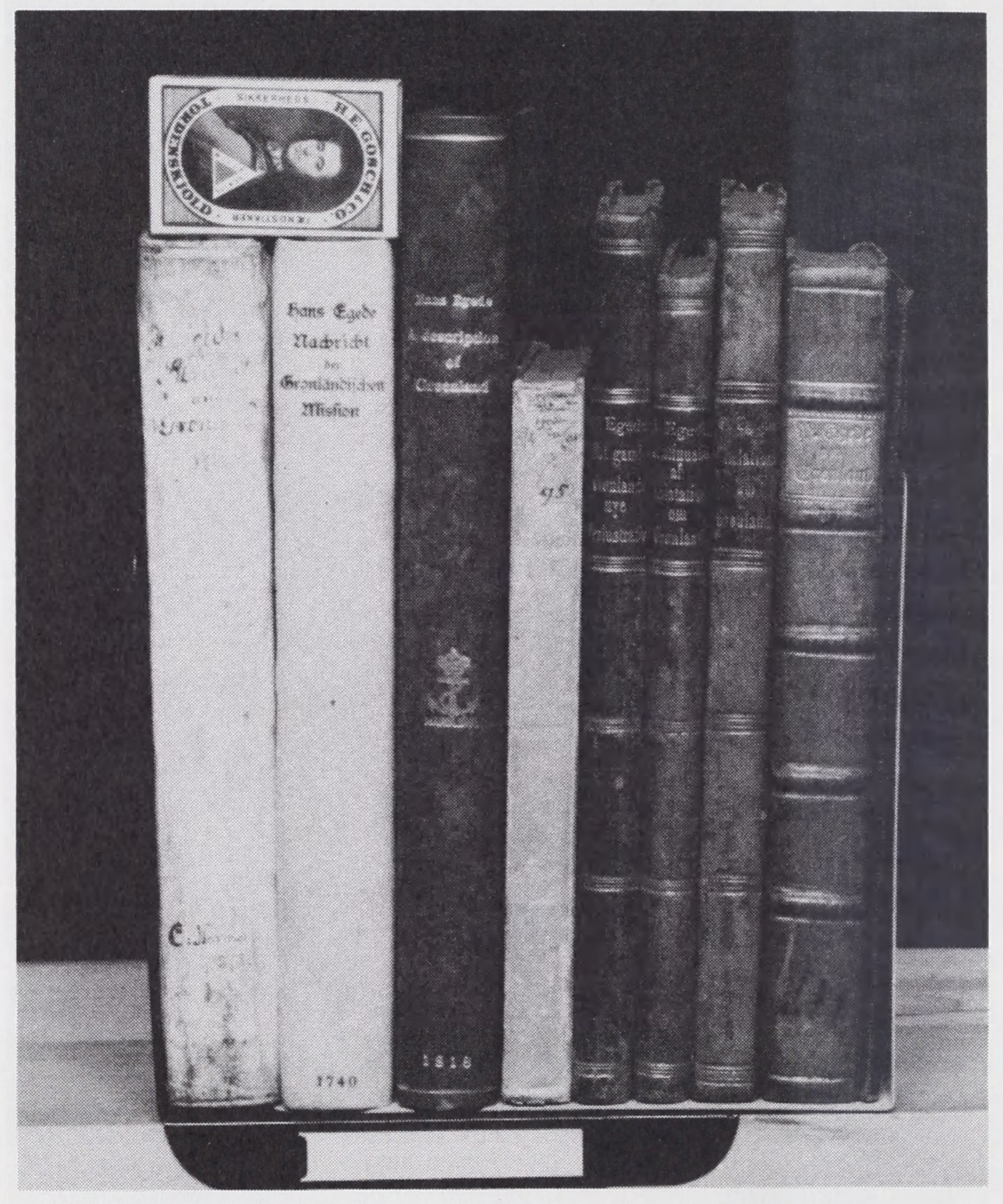


oplevelser, vi ikke fortæller videre. Det er særlig oplagt for Pia Arke, som er født i Grønland, men kun taler dansk. Hun prøver at bryde tavsheden med sin kunst - på den anden side er billeder jo tavse, og nogle gange gør ord mere skade end gavn. Målet for Pia Arke er mere at kommunikere med andre mennesker end at lave ting og billeder, der kan indgå i en karriere som billedkunster. Disse 10 billeder udsprang af samtalerne med Susanne Mortensen i bilen på vej til hospitalet $i$ Frederikssund.

For at vende tilbage til videnskaben, så dukker den op på det billede, der viser en tommestok oven på tre liggende bøger. Tommestokken repræsenterer tallene og kvantificeringen, der er det centrale i den vestlige ide om videnskab. Helt konkret refererer det også til visse målinger, som opdagelsesrejsende foretog af eskimoernes hjerneskaller. Det skete formodentligt i et forsøg på at vise, at naturfolkene var kulturelt tilbagestående på grund af ringere tanke-kapacitet. Her er det imidlertid bøgerne, som måles. Forresten ligner fotografierne af bøgerne stillet op på række i biblioteket også de fotografier, hvor grønlænderne blev stillet op på geled, så de så helt ens ud. Det er nogle billeder, som Pia Arke har parafraseret flere gange bl.a. i Litteraturmagasinet Standart 8. årgang nr. 3 .

Det er også en parodi, der ligger til grund for det komplekse fotografi af tændstikæsken oven på bøgerne skrevet af familien Egede. Når arkæologer har lavet en udgravning og skal tage et fotografi, lægger de en tændstikæske ned i udgravningen, for at man senere kan vurdere størrelsen på genstandene.

Ganske som Hans Egede og de andre opdagelsesrejsende tog til Grønland, er hun sammen med sin tøjhund taget til Christianshavn på en slags ekspedition for at udforske en lige så fremmed verden i form af Marinens Bibliotek. Videnskabsmændene fotograferede grønlænderne på rad og række. Hun har fotograferet bøgerne i geled på hylden. Ganske som videnskabsmændene opmåler med instrumenter og endda forvandler genstande fra hverdagen (tændstikæsken) til måleinstrumenter, så bruger hun de samme redskaber til at måle bøgerne med. Videnskabens egne midler vendes parodisk imod den selv.

Det leder os frem til, hvad der er målet med Pia Arkes konfrontation mellem hendes barndomsveninde og bøgerne i Marinens Bibliotek. Når det kommer til stykket, handler det måske slet ikke om det, en billedanalyse kan sige om de enkelte fotografier. Måske handler det ikke om produkterne, men om akten som er selve fotograferingen.

Fotograferingen har en magt på linje med videnskaben: man ser gennem søgeren og trykker på knappen. Man er den dominerende iagttager. Men fotograferingen har mere end det. Det er en akt, som kan åbne op for en følelse af 
frihed.

Gentagelse er grundlaget for enhver parodi. Man gentager en handling, men gør det med en vis distance. Når Pia Arke som grønlænder, men også som et ganske almindeligt moderne menneske, gentager etnografiens attituder, så åbner det op for et andet rum og en anden tid. Det giver luft, hvor individet har lidt afstand til historiens, institutionernes og identiteternes omklamring. Man får lidt bevægelsesfrihed i forhold til de roller, som man bliver påtvunget udefra.

Det er den opfattelse af fotografering og stil, som er på færde i Arkes værk. Her handler det æstetiske ikke bare om billedanalyse. Det æstetiske åbner et rum for individets eksistens i den moderne verden, sådan som Søren Kierkegaard var den første til at formulere det. 


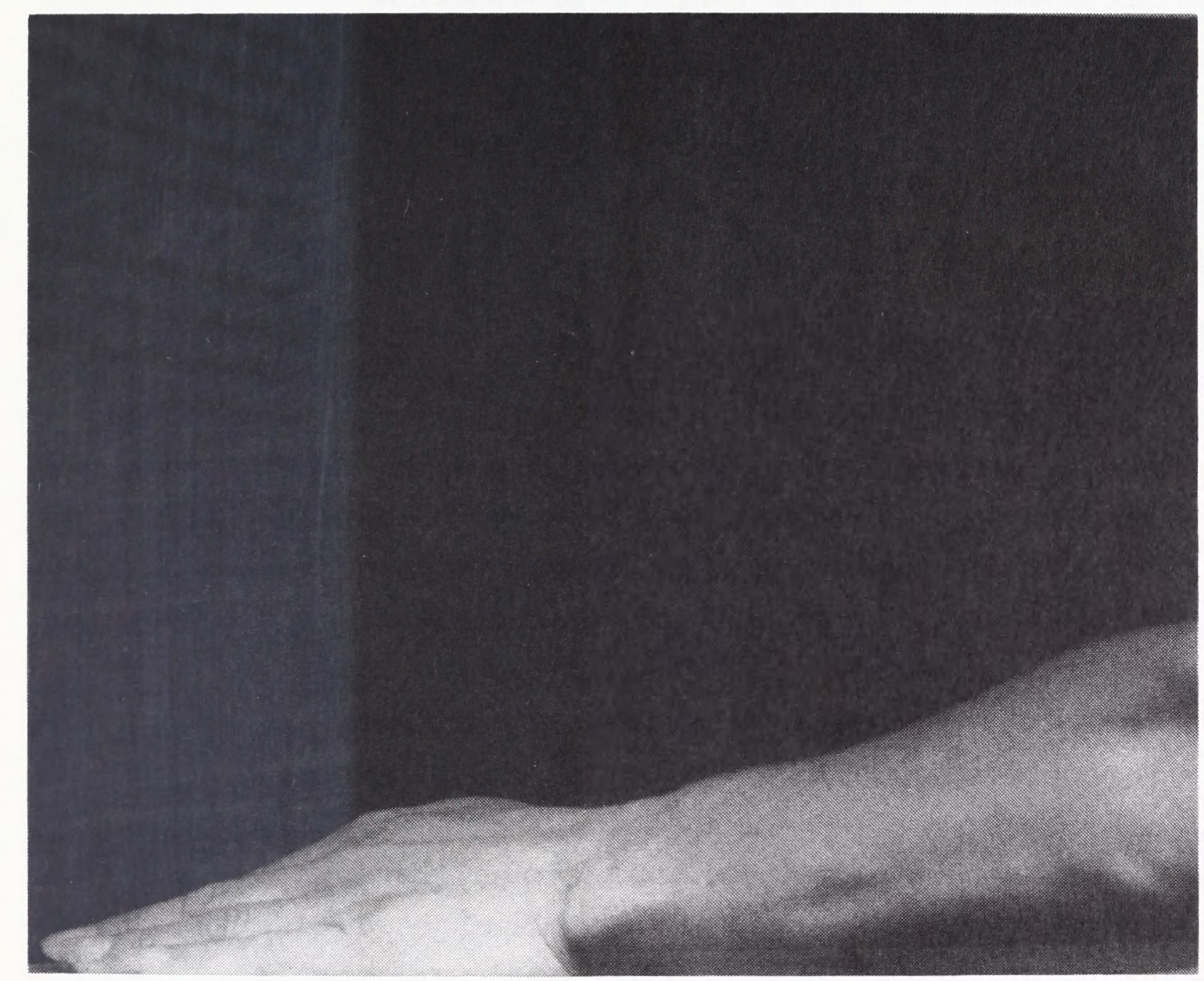

